\title{
The Renewed Constitutional level of Environmental Law in Hungary
}

\author{
By Gergely Horváth*
}

\begin{abstract}
Environmental law is encroaching into the legal system, because it orders the following of the imperative principle of integration, according to which it is necessary to build environmental considerations and priorities into all norms, plans and activities using or affecting the environment.

The highest level of national environmental legislation is the Fundamental Law of Hungary (25 April 2011), which also has new environmentally relevant provisions, which are worth analysingas they serve to protect the natural foundations of life. This assured defence of the interest of future generations stems from the human right to a healthy environment, which is linked to the respect of human dignity and life. This human right belongs to the third generation, the solidarity or collective-developmental group of rights.

The Fundamental Law also comprises several subfields of environmental law by mentioning their protected subjects and emphasizing their importance.

Keywords: human rights, environmental law, Constitution, sustainable development, environmental protection, healthy environment, future generations, natural resources
\end{abstract}

\section{THEORETICAL AND REGIONAL (EUROPEAN) LEGAL ENVIRONMENT}

Environmental law is rapidly encroaching into the legal system just like a liquid „panacea” in blood, ${ }^{1}$ since it requires the following of the imperative basic principle of integration. This principle requires the building of environmental priorities into the process of planning and shaping socio-economic conditions as well as in the executing of all activities affecting the environment. It is because they - at least potentially - may change the state of the environmental media (land, water, air, built environment, and the living elements). The Charter of Fundamental Rights of the European Union also declares in its article on environmental protection ${ }^{2}$ - in connection with the right to a healthy environment (see section 4) - that 'a high level of environmental protection and the improvement of the quality of the environment must be integrated into the policies of the Union and ensured in accordance with the principle of sustainable development.' ${ }^{3}$ Krämer says that 'these provisions are rather misleading as they do not make clear legal situation', ${ }^{4}$ but I can not

* Assistant professor, Széchenyi István University, Győr. E-mail: horvg@sze.hu

${ }_{1}^{1}$ Environmental law verily can be a restorative agent, an instrument of universal remedy of the living planet, of the environment being destructed.

${ }^{2}$ Article 37. of the Charter of Fundamental Rights of the European (2000/C 364/01), 18.12.2000 OJ C 364/5.

3 The paradigm of sustainable development is based on environmental, economic and social pillars and it is necessary to consider all these three aspects in the actual measures, but their diverse importance has to be taken into consideration, especially in case of an interest-collision arising between them. Economic and social sustainability cannot be reached when basic conditions of life are not given, so the conservation of them has to be the prior issue. It is logical that environmental sustainability has the primarcy between the pillars according to the narrower meaning of sustainable development.

${ }^{4}$ Krämer (2012) 150. 
agree with him, because, the word 'must' obviously creates a clear obligation of 'integration' and 'ensurement'. 'Improvement' also clearly means that the level of quality must be improved, can only be made better and no worse. This article - if it is interpreted and implemented with responsibility, regarding the intra-generational and inter-generational equity $^{5}$ - is very stringent. With the words 'a high level of environmental protection [...] must be [...] ensured' it says the same as the well known 'non derogation principle', because this requirement also does not allow any deterioration. It demands at least maintaining the level of protection is ensured, that is why it is not such a cardinal question as to what what should we mean by 'high level of environmental protection'. We must not consider absolute necessity to define the 'high level' (this would be the best alternative of course), because the next part of the sentence calls for improving the quality of the environment. It issufficient to define the measurable and demanded result which is the improved quality of the environment. It is the same whether we consider the level 'high' or not, when the desired effects are successfully reached. Finally, this article is not without a specific addressee. This imperative 'invocation' is addressed to all makers of all the policies and lawmakers of the European Union (not to the ancient Greek gods). However, I admit going along with Bándi - that 'uncertainty is reflected in the method of how the Charter tries to come closer to a right, via listing principles and objectives'. ${ }^{6}$ This article as a 'constitutional' EU-law norm is also a part of the Lisbon Treaty and consequently - in a broad sense - belongs to the 'constitutional level' of applicable, governing environmental law in Hungary.

The principle of integration has a wide impact area, since almost every single economic and social activity in all branches of the national economy are causing environmental effects, even the preparation and creation of a legal norm. In the course of the execution of norms the protection of all environmental elements, the interactions going on between them and the whole environment must especially be ensured. The legal aspect of environment protection, as a 'cross-lying' area of law and the horizontal natured environmental politics have to prevail spectacularly inside other fields of law and in politics, too. This is a 'sine qua non' of its efficiency. Nonetheless, it is an uncompromising necessity to raise the level of protection of natural resources and other essential elements of the environment. This is not possible without cutting back or completely blocking the environmentally harmful forms of economic activity. Moreover, environmental losses collide directly or indirectly with human self-interest as well, so even utilitarianism could justify the strict environmental measures. ${ }^{7}$ The Seventh Environmental Action Programme of the EU, the title of which is 'Living well within the limits of our planet' is inconsistent in the state of 'overshoot' ${ }^{8}$ The 'growth' - with any kind of indicative or adjective before - cannot be sustainable in a

5 In respect of the vital environmental interests of the present and the future generations.

6 Bándi (2014) 89.

7 Not only do biodiversity loss and the degradation of ecosystems in the Union have important implications for the environment and human well-being, they also have impacts on future generations and are costly for society as a whole, particularly for economic actors in sectors that depend directly on ecosystem services. [Decision 1386/2013/EU of the European Parliament and of the Council of 20 November 2013 on a General Union Environment Action Programme to 2020 'Living well, within the limits of our planet', Preamble (23) par. OJ L 354/171 28.12.2013]

8 See Catton (1980) 30.

Earth Overshoot Day 2015 landed on August 13, marking the date when humanity has exhausted nature's budget for this year. 
biophysically finite world. Since the current prevailing governmental aim is - practically in each country of the world - the upgrowth of economic production, this 'cross-cutting' promises to be a bumpy road, also in Hungary.

The highest level of national environmental legislation is the Fundamental Law of Hungary (25 April 2011). ${ }^{9}$ The environmentally relevant provisions of this norm - in spite of their high level of abstraction - can determine and serve the practice comprehensively and most effectively. The affirmation of the constitutional environmental law in Hungary is established. Fortunately the stage of drafting the new constitution when the human right to a healthy environment was omitted has been overcome. The new norms are true to the opinion of the Constitutional Court, that says

'the human right to a healthy environment provides the physical conditions of the success of the right to life. All this requests is an increased, special protection of it through legistation, compared to other rights" [Decision 28/1994 (V. 20.) of the Constitutional Court (CC)].

That is why it is vitally important that the constitutional fundament of the 'four Musketeers' of the protection of the natural foundations of life is fortified. These are environmental protection (the environmental pillar of sustainable development), nature conservation (protective regime of endangered, vulnerable, rare species), habitat protection (an indispensable tool of modern conservation with network-approach) and the protection of the living world (raising a shield over every living organism). All these four protective systems (with their legal aspects) make an effort to protect the natural bases of life, which are threatened by damaging and the over-consumtion of mankind.

Nevertheless the human desire to fully harness nature will not succeed ${ }^{10}$ in the XXI ${ }^{\text {st }}$ century either. In ancient China's 'holy book' of the I Ching, 'People can not change the well.' Life will always depend on the same basic conditions. The well from which we can draw water, includes the idea of an inexhaustible supply of donations as well. The well is one of humanity's most primitive social organization of needs-based view of life, which is independent of any political regime.

Man is not able to revamp the natural foundations of life. This also means that it is his or her moral duty to respect them. Understandably, however, we cannot do anything to change these funds, because man-made things are fleeting. They all, as well as their implications vanish in time. Thisis actually good news in an environmental context.

The regulation of the protection of the environment is still anthropocentric despite the formal acknowledgement of natural values. The best example is the conventional definition concerning the 'biological resources', ${ }^{11}$ which also reflects a purely anthropocentric view, that they include 'genetic resources, organisms or parts thereof, populations, or any other biotic component of ecosystems with actual or potential use or value for humanity'. So we are the measure. Quoting Protagoras: 'homo mensura'.

Naturally we could not give up the benefits of biodiversity even if the population of the world still only measured some million. Values are shifting in the direction of materialistic utilitarianism, and the requirement of the expected continuous growth directly leads to consuming of resources and to the exhaustion of the ecosystem services (all benefits

9 It came into force on 1th January 2012.

10 Meaningful information can be mentioned as a warning: in 2011 for example, more than 300 billion EUR economic loss was caused by climate change worldwide partly due to disasters, and this is just the economic loss.

11 Convention on Biological Diversity (CBD) art. 2 
people obtain from ecosystems ${ }^{12}$ ). Efforts to develop legal regimes to control global environmental problems are likely to become even more challenging in the future as the extent of such problems becomes more apparent. ${ }^{13}$ Nowadays, beside the leading material viewpoints, "non-profit", ecological ideas still exist, free from economic considerations and according to commands of conscience.

The protection of the interest of the following generations stems from the claim of the intergenerational equity, the human right to a healthy environment is linked to the respect of human dignity and life. The protection of the environment is made independently of humanity's interests and is conceived in the renouncement of human conceit. In order to make this triple defensive regime efficient, it is necessary to transform the entire legal system, as the direct object of the regulation, human behaviour should be environmentally aware as far as possible. The Fundamental Law of Hungary obtains an important role in achieving this aim. 'It is the turn of enforcement.'

\section{THE CONCEPT OF ENVIRONMENT}

The concept of environment comprises all that which surrounds a living being, affects it and insures its existence. ${ }^{14}$ Fodor ${ }^{15}$ also includes the reaction as a concept creating factor, which is typical, but not exclusive (the solar radiation as an active component is a good counterexample). In the case of a human being the key issue is this reaction upon the natural system, ${ }^{16}$ the human impact which should be altered and reduced. The choices and the chosen ways of satisfaction of their needs should be made less harmful. These are the tasks of environmental law. As a matter of fact the difficulty and also the solution of the problem is that everybody has the decision to change lesser or greater elements of his or her lifestyle. According to Hubert Reeves, the Canadian astrophysicist being worried about the future 'pollution in the world is not one major problem, it is seven billion small problems. ${ }^{\text {' }}$

As Bell and McGillivray state, used in a broad sense environmental law could include virtually anything. Indeed, as Einstein is said to have remarked 'the environment is everything that isn't me' (even this however does not present the whole picture as Einstein himself was also part of it). ${ }^{18}$ According to the Hungarian legal definition, environment comprises the environmental components, the systems, processes, and structure thereof. ${ }^{19}$

12 Ruhl (2007) 164.

Agricultural production is an example of a provisioning ecosystem service, though the agricultural export sector does not internalize impact on ecosystem services. See Gathii (2012) 12, 17.

13 Percival (2007) 32.

14 Földi (2009) 23.

15 Fodor (2007) 9; Fodor (2014) 11.

16 Natural (ecological) system: dinamic and natural unity of the living organisms, their community, and their abiotic environment [Act LIII. of 1996 on the protection of the nature, 4. $\S, \mathrm{k})$ ].

17 D’Ansembourg (2007) 184.

18 Bell (2006) 7.

19 Act LIII. of 1995, Kt., 4. $\S 1$.

Environmental components are: land, air, water, the biosphere as well as the built (artificial) environment created by humans, furthermore, the constituents thereof (Act LIII. of 1995, Kt., 4. § 2.). As used in the 1979 Geneva Convention on Long-range Transboundary Air Pollution (LRTAP Convention), the environment includes 'agriculture, forestry, materials, aquatic and other natural ecosystems and visibility' [Art. 7(d)]. 


\section{DEFINING THE TERM OF ENVIRONMENTAL LAW}

Environmental law is one of the fastest growing fields of law across Europe, which is also testified by the new European Union's environmental action plan. ${ }^{20}$ Environmental protection and its legal aspect is invaluable, because - according to the principle of prevention - it protects humanity itself from suffering, losses which are consequences of causal effects of pollution and misuse of the environmental elements. Environmental law and environmental protection are means and aim. They are complementary to each other, and often leave white spots on the canvas of our environment. ${ }^{21}$

The Act on the general rules of protection of the environment (Act LIII. of 1995) gives a normative definition of environmental protection, which - a narrow interpretation - does not cover the behaviours which are the target of the improvement of the state of the environmental media (e. g. melioration, drainage, habitat development works) in case of the lack of an earlier damaging activity. According to this definition environmental protection is the totality of all the activities and measures aimed at the prevention of things that pose a hazard to, damaging or polluting the environment, the reduction or elimination of damage that has developed, and the restoration of the state preceding the damaging activity. Consequently this concept of environmental protection should be used valiantly in the widest sense in my opinion. The Act LIII. of 1995 encourages this, since it defends the environmentin the widest sense of the meaning .

Since environmental law is the legal aspect of environment protection, its legal concept is to be taken as a starting point, and the concept of this area of law can be created with importing the above mentioned absent elements and finally completed with the requirement of precaution. Environmental law is the totality of those norms, provisions and measures, that are aimed at (or rather result in) a precautious use of environment, ${ }^{22}$ and at the prevention from the negative consequences of the human activities and omissions, at their reduction or even stopping, and aimed at restoring and improving the state of the environment. Those normative regulations are also part of this area of law which are of a technical character and the mentioned aims cannot be required from them (such as the designation of authorities of nature conservation).

Sands also defines international environmental law with its aim, but narrows it by using the criterion of 'primary objective'. He says that this area of law comprises those substantive, procedural and institutional rules of international law which have as their primary objective the protection of the environment. ${ }^{23}$ This is too stringent in my opinion, because it can be enough to have this as a secondary objective, or not even have it at all as a goal, only being effective in achieving environment-protective results. In this case the result is the measure of the norm, it does not matter in which field of law it was included earlier. Erbguth and Schlacke also write that environmental law includes all norms made by the state, which serve the protection of the environment and in many cases, there are provisions in acts which were not primarily made to regulate the environmental protection. ${ }^{24}$

20 Kerschner (2014) 1.

21 Julesz (2003)

${ }^{22}$ Use of environment: activities entailing the load or strain of the environment or its elements [Kt, 4. § 9.].

${ }^{23}$ Sands (2003) 15.

24 Erbguth (2012) 43. 
I do consider all regulations as an environmental law norm, which are not made with an environment protection aim originally, but are suitable and efficient to achieve the aim of protecting the environment. Council Directive 70/157/EEC of 6 February 1970 on the approximation of the laws of the Member States relating to the permissible sound level and the exhaust system of motor vehicles is an appropriate example, that proved to be an excellent norm of environment protection. Today it is unambiguously the protection against noise and the human right to a healthy environment which come to our minds as being a primary aim while reading the regulation of the noise standards of motor vehicles, rather than the economic aim being connected to the undisturbed functioning of the market.

I am of the opinion that all borders of environmental law are to be treated elasticly stemming from the requirement of the principle of exterior integration of environmental law. The dogmatic positivism has less place in these cases. The rigid binding to the environmental protection aim is also problematic because it would be necessary to exclude some environmental procedural law provisions, too, since they (e. g. 'the procedure deadline in the natural conservation magisterial licensing procedures is three months') do not inevitably carry any environment protection aim.

Sands' definition is debatable mostly on this point, since he would require the primary environment protection aim in case of the procedural law regulations as well.

Returning to our national environmental law with an example, notwithstanding that it lacks environmental protection aims, the environment protection authorities' designation is a question of environmental regulation. Although the governing law [edict 347/2006. (XII. 23.) on the designation of the organs performing administrative tasks of environmental protection, nature conservation and water management], considering its aim would not be an environmental law norm in this narrowed meaning.

However, the most important regulations of this area of law are in the new constitution, which defends the natural resources in several articles, mostly concerning the interests of the next generations, defines special objects of the fields of environmental law, and acknowledges the human right to a healthy ${ }^{25}$ environment.

\section{THE HUMAN RIGHT TO A HEALTHY ENVIRONMENT}

A simplifying solution spreads universally in the environmental literature, that we merely talk about a 'right to environment'. This is meaningless, since everybody has an environment, we are surrounded by environmental elements in all circumstances. Thus the question is, in what quality of state this environment is, so some adjective is necessary to be placed in front of the questionable right. Due to the anthropocentric nature of the regulation several attributes appear in the literature, in the national laws and in the international documents: ecologically balanced, qualitative, healthy (not jeopardizing human health), safe (peaceful, free from chemical or nuclear arming), undisturbed (relaxation, regeneration not disturbing) adequate (appropriate) ${ }^{26}$ or aesthetic (high landscape value, landscape potential) environment.

25 Because environmental conditions can play a significant role in the development and spread of new diseases, it seems logical to believe that the fields of environmental law and health law will begin to converge. So many issues of public health and preventive medicine already revolve around environmental conditions that it is a logical progression for both fields of law. See Percival (2007) 33.

26 Kilényi (1979) 131. 
However, it is a human right so all expressions are to be understood in such a way that it is safe, aesthetic, healthy and so on for human beings, not jeopardizing their health, satisfying their needs. Human health may be seen as the most significant bridge between human rights and environmental protection, being a primary objective of both areas of regulation. ${ }^{27}$ According to the new Fundamental Law 'Hungary also shall promote the effective application of the right to physical and mental health by an agriculture free of genetically modified organisms, ${ }^{28}$ by ensuring access to healthy food and drinking water [...], as well as by ensuring the protection of the environment' (Article XX.).

'Healthy' can be an indicative of status (accustomed to use to active organisms) and it is also used in a sense of 'harmless or even improving health conditions'.

'Healthy air' means that it is not harmful for humans, and does not mean the wholesomeness of the atmosphere. The concept of 'environment and health' is a bit misleading in Hungarian. The Hungarian word 'környezetegészség' could rather express the healthy state of the environment, but the real notion is about the contact of the environment and human health. The World Health Organisation (WHO) defines 'environment and health' as including 'both the direct pathological effects of chemicals, radiation and some biological agents, and the effects (often indirect) on health and well-being of the broad physical, psychological, social and aesthetic environment, which includes housing, urban development, land use and transport.' 29

The Aarhus Convention ${ }^{30}$ is the clearest statement in international law declaring the fundamental right to a healthy environment. The Convention's objective is stated in Article 1 , where it refers to the right to a healthy environment as a concrete and accepted fact. ${ }^{31}$ The preamble of the Aarhus Convention which is also part of the Hungarian legal system helps the interpretation by proclaiming that every person has the right to live in an environment adequate to his or her health and well-being, and the duty, both individually and in association with others, to protect and improve the environment for the benefit of present and future generations. [...] Adequate protection of the environment is essential to human well-being and the enjoyment of basic human rights, including the right to life itself. ${ }^{32}$ These lines make it unambiguous, that the right to a healthy environment is really human, it is not the environment's right. If it would be the latter's, then we should use terms like 'undisturbed', 'free from polluting or intervening', 'untouched' and so on as attributes.

It does seem possible to define the human right to a healthy environment with precision for it to be submitted to the scrutiny of the courts, in particular the European Court of Human Rights. It is now generally accepted that the right to a healthy environment includes

27 Shelton (2006) 170.

28 This mere declaration is clearly not enough to protect the country against this new form of aggression. See Raisz (2012) 49.

29 "Environment and health. The European Charter and commentary", Copenhagen, WHO Regional Office for Europe, 1990 (WHO Regional Publications, European Series, No 35).

30 Convention on Access to Information, Public Participation in Decision-Making and Access to Justice in Environmental Matters, adopted in Aarhus, Denmark on 25 June 1998.

31 Giorgetta (2002) 187.

32 Act LXXXI. of 2001 on the promulgation of the UNECE Convention on Access to Information, Public Participation in Decision-making and Access to Justice in Environmental Matters, the Aarhus Convention, signed on June 25, 1998, 2. § 
two complementary dimensions: a procedural and a material or substantive dimension ${ }^{33}$ (the above mentioned Aarhus Convention deals with the procedural rights).

The notion of the right to a healthy environment (not yet expressed in these words ${ }^{34}$ ) appeared for the first time in the Principle 1 of the Stockholm Declaration of the United Nations Conference on the Human Environment. ${ }^{35}$ The Expert Group on Identification of Principles of International Law for Sustainable Development stated that "the right to a healthy environment provides a focus to guide the integration of environment and development. Development is sustainable where it advances or realizes the right to a healthy environment." 36

This human right belongs to the third generation of human rights, to the solidarity or collective-developmental group of rights, with a global effect and referring to all of humanity. These rights can be covered - according to the pathetic train of thought of Vasak ${ }^{37}$ - with part of the slogan 'fraternity' of the well-known triple slogan of the French revolution. The demand of the accurate quoting and completeness requires that we mention the whole of the slogan which has four elements in fact: "Freedom, equality, fraternity - or death" ("Liberté, égalité, fraternité, ou la mort").

It is interesting that already the classification step of the fourth generation of human rights $^{38}$ is spreading in the new millennium, such as the legal aspects of bioethics. So the picturesque parallel of Vasak can be completed: euthanasia adhering to the right of the patient's right to private autonomy, the right of the refusal of medical treatment and all the issues of the end of life decisions (see the last word:"death") belong to the fourth generation, too.

The failures of ensuring the right to a healthy environment show that the mentioned quadruple slogan is - looking at our relation to the environment and its consequences shockingly apt. The relationship between the right to a healthy environment and the right to life is really direct. The unlimited freedom of mankind, over the centuries has expanded and placed an unnecessarily heavy burden on the environment . Everybody is equally capable of the over-consumption of the natural resources due to the expansion of living standards due to economic and social development. We also recognize the need for fraternity, the honest discernment of the necessity of the protection of the environment. This appears beneficial or even glorious, but this all-time tragedy catches up with the man: he knows the right way, but does not keep to the path. We have known for decades that the endless economic

33 Bota (2009) point 19. Also see for example Mova Al 'Afghani (2006).

${ }^{34}$ It is attributed to Karel Vasak to use the appellation 'right to a healthy environment' in 1977 for the first time ever. See Farkas Csamangó (2014) 13.

${ }^{35}$ Stockholm Declaration, part II (Principles), Principle 1: 'Man has the fundamental right to freedom, equality and adequate conditions of life, in an environment of a quality that permits a life of dignity and well-being, and he bears a solemn responsibility to protect and improve the environment for present and future generations.' As we can see, the 'rights' of future generations also appeared in this document.

${ }^{36}$ Report of the Expert Group Meeting on Identification of Principles of International Law for Sustainable Development, Geneva, Switzerland, 26-28 September 1995, paragraph 31.

37 See Vasak (1977) 29-32.

38 "At present, we are witnessing what could be called a fourth generation of fundamental rights, or a generation of rights and duties for the society of the future. [...]That is quite simply the principle of solidarity between generations". See Bota (2009) point 12.

Also see for example Mova Al 'Afghani (2006). 
increase cannot be maintained on a finite planet forming a closed system. The aim is the endless expansion in the finite. That visibly leads to local tragedies (see the consequences of climate change), then to a global environmental crisis, to migration of billions and leads to the decimation of humanity. "Freedom, equality, fraternity - and death."

Let there be debates - of course - about how to use and value the natural world, but these "debates get persistently entangled with questions of honor or status - questions about whose way of life is best". ${ }^{39}$ Whilst we do not "have an ear to hear", we consider death caused by environmental pollution a distant, unimaginable, exaggerated prophecy. The person who has already lost a friend or relatives owing to an illness generated by the chemical revolution is certainly not of this opinion. The 'cocktails' consisting of the solution of the chemical agents swirling in our blood or black lungs caused by metropolitan air conditions are well-known mortality causes.

The right to life - considering its circle of subjects - must be interpreted broadly, since also the existence of the future generations is in the balance. The right to life is jeopardized by the omissions of the protection and conservation of the natural heritage and the environmental values. The lack of care for inter-generational equity and justice may also affect the descendants' right to human dignity. The state of the environmental elements may be so bad in the future, that man be hardly unable to to live in $i^{40}$ (see for example the inhuman slums or even the pictures of mountains of waste in the streets of the beautiful Naples, with a smell which cannot be documented).

Rights and obligations generally walk hand in hand in a complementary manner, but it is not necessary to insist on this theoretical structure in the case of all life-relations. The efficiency of environmental law does not depend on this. In case of the right to a healthy environment the position of the oblidged (the state) and the lawful subjects (everyone) is clear in the new Fundamental Law: Hungary shall recognise and give effect to the right of everyone to a healthy environment (article XXI). On the side of the state there is an active behaviour (forming of legislation, an organization system and guaranteeing its operation, the protection itself) and also the obligation of passivity (having respect for the rights of the coming generations, abstaining from their depreciation),. Whereas the obligation of the rest of the subjects of law is the careful and tactful usage of the environment. This obligation is underlined by the Fundamental Law from the perspective of the consequences: 'anyone who causes damage to the environment shall be obliged to restore it or to bear the costs of restoration, as provided for by an Act'. ${ }^{41}$ We must admit that this is unfortunately a narrowing interpretation of the polluter-pays principle, because the "polluter" has to bear also the costs of prevention of an avoidable environmental damage. ${ }^{42}$

The Constitutional Court stated that the 'objective side' of this human right, the 'institutional protection' is dominant [Decision 28/1994. (V. 20.) CC]. In this context, 'objective' means that the state can determine the environmental requirements on the basis of objective criteria, that is, instead of the individual needs of the people, in general, rather

39 Purdy (2012) 172.

That is why 'environmental law is structured by conflict' states Purdy later. See Purdy (2012) 172.

40 See the aim of insuring the proper conditions of inhabitability in the new fundamental law (article XXII).

41 Article XXI (2).

42 Horváth (2011) 87-88. 
to protect the natural foundations of life. ${ }^{43}$ Therefore, individuals cannot sue for example the state in order to satisfy their subjective environmental needs (eg. healthy air of forest quality and perfect silence in the center of Budapest).

Constitutional declaration of the right to environment is a frequent but not an exclusive constitutional solution in connection with environmental protection. Some countries declare specifically only some parts of this right (e. g. the Polish Constitution declares specifically only the informational part of $i^{44}$ ). Others approach the question as duty and responsibility of the state (e.g. in Austria the legislative subjects' division is precisely elaborated ${ }^{45}$ in relation to environmental protection). ${ }^{46}$ Finally, there are countries where the constitution does not mention environmental protection neither as a right nor as the duty of the state (e.g. Denmark, Ireland). Nowadays this is not a problem, because protecting the environment is implicitlypart of the order of constitutional values and human rights, because the protection of other values (life, health, property, private housing) is not possible without it. ${ }^{47}$

\section{THE SPECIALITIES OF ENVIRONMENTAL LAW IN THE NEW FUNDAMENTAL LAW}

The Fundamental Law names several subfields of environmental law by mentioning their protected subjects emphasizing their importance. The subfield dealing with the environmental risks of genetically modified organisms (mentioned in article XX). This article is an appropriate example for understanding the underlining reasons for the reasons of its appearance in the new constitution. The most important causes are highlighting, such as the national economic significance, the strategic natural resource character. Actual legal cases which arise and are connected to the objects of the questionable specialities envisoned by a public interest establish why politics has responded to them with this symbolic step of inclusion. The general prohibition of growing genetically modified organisations at the constitutional level seems to be the suitable device of the prevention of the irreversible consequences. The justification of this step was brought in the summer of 2012 when some 'accidentally' sown polluted corn were found in Hungary.

Article XXI. paragraph (3) flashes the waste management speciality by enunciating that 'the introduction of pollutant waste into the territory of Hungary for the purpose of disposal shall be prohibited'. It is the expression of actual public (un)will recognised in connection with a case (former illegal waste 'import' from Germany). It is also a characteristic example of the unique constitutional objects at the renewed constitutional level of the Hungarian environmental law.

43 Fodor (2014) 106.

44 Everyone shall have the right to be informed of the quality of the environment and its protection. (The Constitution of the Republic of Poland of 2nd April, 1997 Article 74)

45 Schnedl (2014) 86-93.

46 Environmental protection is counted as cross-sectional field based on the cross-sectional clause ("Querschnittsklausel"), thus it is not covered only by one legislative competence, but is shared by the state and the competence of the provinces.

47 Fodor (2014) 104. 
Article $\mathrm{P})^{48}$ claims the general protection of our natural resources as a requirement in the spirit of inter-generational equity and the goal of sustainable development ${ }^{49}$ as underlying philosophies. The exemplificative enumeration of the specific natural resources ${ }^{50}$ 'which all form part of the common national heritage' means a kind of illustrative 'roll call' of the specialities of environmental law. The reference to arable land represents the subfield of law of the protection of land (and soil conservation), that of the water resources represents the subfield of water protection, the reference to forests and the biological diversity, the endemic plants and animal species visualize the speciality of nature conservation, the highlighting of the cultural values represents the area serving the protection of the artificial (built) environmental element.

The mentioned protected legal objects constituting the nation's common heritage metonymically melt with their protective regimes, strengthening them by forming constitutional reference to the grounds of law.

\section{THE PROTECTION OF THE INTERESTS OF FUTURE GENERATIONS IN THE FUNDAMENTAL LAW ${ }^{51}$}

The solidarity character of the right to a healthy environment consists of several layers. This characteristic results in the necessity and obligation of the collaboration of states, since the global environmental problems can only be solved this way. The state to state relation is formulated in the first paragraph of article Q), that 'in order to achieve the sustainable development of humanity, Hungary shall strive for cooperation with all the peoples and countries of the world'.

The second aspect, in which the right to healthy environment appears most vividly on a daily basis is the scene of interactions between people. For example, the respector of law releases smokes only in designated places and respect the others claim toclean air.

The third aspect can be discovered between the state and the individual, the latter is rightful and the state is obliged to insure that right.

The fourth aspect carries an interesting, subjective question which cannot easily be handled by the law. It is about the acknowledgement of future generations' interests and rights by all subjects of law currently in the position of the user of environmental elements. 'Each generation makes its own relation to the natural world, though in circumstances it

48 Supplemented by Article 1 of the Third Amendment to the Fundamental Law (21 December 2012)

49 Sustainable development is development that meets the needs of the present without compromising the ability of future generations to meet their own needs (World Commission on Environment and Development, Our Common Future, UN Documents, A/42/427 Chapter 2: Towards Sustainable Development.1987). The reference of the needs of the present generations appearing in the definition refers to the social sensitivity of the authors of the report - emphasizes Szabó (2012) 162.

50 "In particular arable land, forests and the reserves of water, biodiversity, in particular native plant and animal species."

${ }^{51}$ Future Generations' interests increasingly appear in National Constitutions recently. See the German Constitution art. 20a., Constitution of Cuba art. 27., Sweden Constitution art. 2 sentence 4., French Charter for the Environment, the preamble of the Ukraine Constitution or the Swiss Constitution for a beautiful example. 
does not choose, and yet must understand, in order to change them'. ${ }^{52}$ Nevertheless, our relation to the natural world determines the possibilities of the following generations.

The Fundamental Law lays down firmly in the Awoval that 'we bear responsibility for our descendants; therefore we shall protect the living conditions of future generations by making prudent use of our material, intellectual and natural resources'. ${ }^{53}$ Article P) also states that 'natural resources, in particular arable land, forests and the reserves of water, biodiversity, in particular native plants and animal species, as well as cultural assets shall form the common heritage of the nation; it shall be the obligation of the State and everyone to protect and maintain them, and to preserve them for future generations'.

It does not appear beneficial, that the institution and Office of the Parliamentary Commissioner for Future Generations was terminated, even if the commissioner for fundamental rights and his office took over the tasks as a legal successor. This step is euphemisticly appreciable as the part of the integration process of the environment protection interests (institutional integration), but the reality is that the protection of interests of the future generations has lost an organizational guarantee. The Commissioner was actually a special environmental ('green') ombudsman, whose principal responsibility was to safeguard citizens' constitutional right to a healthy environment.

The protection of the natural resources, and the respect of the needs of the coming generations also appears in the Fundamental Law as the aim of the protection of national property: 'The management and protection of national assets shall aim at serving public interest, meeting common needs and preserving natural resources, as well as taking into account the needs of future generations' ${ }^{54}$ The issue of the environmental components becomes interwoven with the financial relations tightly, since land and water treasure forms a considerable part of the national property. Land must represent a very high ratio within the national assets of Hungary and this proportion and value will dramatically rise in the future, especially in case of the foreseen lack of food resources. Its importance is due to the public interest and utility of a wide range of vital functions associated with it. ${ }^{55}$

The practical question is, what is to be done in order to safeguard future generations? "It is better to pass on the freedom of choice to the future generations than to anticipate their interests. So it is best to conserve the goods for them." ${ }^{56}$ This refers to all environmental components.

\section{THE PROTECTION OF THE NATURAL FOUNDATIONS OF LIFE ${ }^{57}$}

The 'living environmental component' also represents a huge value in Hungary (see e. g. sylvan usufructs). Economists have dealt with the estimation of the value of biological diversity for a long time. The variety of flora and fauna elements and the accumulation of the races is an important feature of the biogeographic picture of the Carpathian Basin. The conservation of these values requires norms providing a constant level of protection. The

52 Purdy (2012) 228.

53 8. sentence of the „AVOWAL".

54 Art. 38. (1)

55 Horváth (2013) 359.

56 Sólyom (2011).

57 It was the Constitutional Court which used this expression for the first time in 1990, when establishing that "the state's duties should include the protection of the natural foundations of life" (996/G/1990 AB, ABH 1993, 533, 535.) 
Constitutional Court declared, that the state may not reduce the level of the nature conservation and environmental protection with measures, only if it is unavoidable in order to ensure other fundamental rights or constitutional values [Decision 28/1994. (V. 20.) CC]. This necessity-proportionality test and non-derogation principle is important for the sake of maintaining biodiversity. The Hungarian Constitutional Court also ascertained that the level of protection is decisively influenced by the subject of environmental protection: the natural foundations of life are finite and a significant portion of damages are irreversible and finally, the fact that all of these conditions are prerequisites of the continuation of human life [Decision 28/1994. (V. 20.) CC]. The defense ergo - despite the usage of article XXI. - is clearly and exclusively refers to humans ('everyone'), who the protection necessarily having regard to - not purely anthropocentric, is also nature-centered. ${ }^{58}$ Thus the protection cannot be limited solely to human living conditions. Those are also topical, but it is not limited to this area, even the natural foundations of life are included in general as well. ${ }^{59}$

We can say that the new Fundamental Law is more environment-conscious and ecocentric than the old constitution was, which can already be concluded from the beginning where it is stated: we "commit to promoting and safeguarding our heritage, [...] all manmade and natural assets of the Carpathian Basin". ${ }^{60}$

\section{CONCLUSIONS}

The new Fundamental Law raises the level of protection of the natural bases of life as compared with the old constitution. Unlike its predecessor, it deals with environmental matters in not only two sentences, but several new articles are mentioned in connection with natural resources and the interests of future generations. There are even some unique constitutional objects at the renewed constitutional level of the Hungarian environmental law (e.g. the general prohibition of growing genetically modified organisations). Despite this a systematic approach and coherence which would be expected also from the constitutional level of environmental regulations cannot easily be discovered. These "green requirements" are of different depths (general or belonging to specialities), they are scattered, and appear sporadically in the text. The most important innovation is that it displays both inter-generational and intra-generational equity, as well as fills the norms specifying responsible management of natural values and resources with the sense of community, with a kind of spiritual essence. This - in a fortunate and desired case pervades the legal system as a whole, supporting the implementation of the principle of integration also required by the law of the European Union.

According to the mentioned articles related to environmental protection we can ascertain that de iure "Hungary follows a way to become an eco-social market economy", ${ }^{61}$ de facto nevertheless all depends on the mentality, intentions and value choices of the executive, the judiciary and the subjects using the environment.

58 Fodor (2014) 110.

59 Fodor (2006) 56-57.

60 8. sentence of the „AVOWAL”. Using the name of Carpathian Basin is not just a theoretical issue, but has considerable practical benefits as well for example in case of nature conservation. See the so called Pannonian biogeographical region, or ecoregion of the EU's Natura 2000 network). See further Bándi (2013).

61 Julesz (2012). 


\section{LITERATURE}

Bándi, Gy., A fenntarthatóság értelmezésének egyes jogi szempontjai [Certain Legal Aspects of the Interpretation of Sustainability] (Pázmány Péter Katolikus Egyetem 2013)

Bándi, Gy. (ed) Environmental Democracy and Law (Europa Law Publishing 2014)

Bell, S., et al., Environmental Law (6th edn, Oxford University Press 2006)

Bota, JM., 'Explanatory memorandum of Drafting an additional protocol to the European Convention on Human Rights concerning the right to a healthy environment' Council of Europe Parliamentary Assembly Report Doc. 12003 (11 September 2009) <http://assembly.coe.int/nw/xml/XRef/XrefXML2HTML-en.asp?fileid=12279\&lang=EN> accessed 29 May 2015.

Catton Jr. and William R., Overshoot: The Ecological Basis of Revolutionary Change (University of Illinois Press Urbana 1980)

D’Ansembourg, T., Being Genuine: Stop Being Nice, Start Being Real (Puddle Dancer Press 2007)

Erbguth, W. and S. Schlacke, Umweltrecht (4th edn, Nomos 2012)

Farkas Csamangó, E., Környezetjogi szabályozások [Environmental Law Regulations] (SZTE ÁJK JATEPress 2014)

Fodor, L., Környezetjog [Environmental Law] (Debreceni Egyetemi Kiadó 2014)

Fodor, L., Környezetvédelem az alkotmányban [Environmental Protection in the Constitution] (Gondolat Kiadó 2006)

Fodor, L., Környezetvédelmi jog és igazgatás [Environmental Law and Management] (Debreceni Egyetemi Kiadó 2007)

Földi, L., et al., Környezetbiztonság [Environmental Security] (Complex 2009)

Gathii, J. et al., 'Curtailing ecosystem exportation: ecosystem services as a basis to reconsider exportdriven agriculture in economies highly dependent on agricultural exports' (2012) 30 Virginia Environmental Law Journal 1-27.

Giorgetta, S., 'The Right to a Healthy Environment, Human Rights and Sustainable Development' (2002) 2 International Environmental Agreements: Politics, Law and Economics 173-194.

Horváth, G., 'Protection of Land as a Special Subject of Property: New Directions of Land Law' in P Smuk (ed) The Transformation of the Hungarian Legal System 2010-2013 (CompLex Wolters Kluwer 2013) 359-366.

Horváth, Zs., et al., 'Környezetvédelem és fenntarthatóság az új Alaptörvényben' [Environmental Protection and Sustainability in the New Fundamental Law] in T Drinóczi (ed) Magyarország új alkotmányossága [The New Constitutionality of Hungary] (Pécsi Tudományegyetem Állam- és Jogtudományi Kar 2011) 77-96.

Julesz, M., 'Interdisciplinary fields of environmental law and new branches of civil law' Journal of Legal Theory (3rd issue, 2003) <http://jesz.ajk.elte.hu/julesz15.html> accessed 8 April 2008.

Julesz, M., 'The New Hungarian Constitution (Basic Law) of 2011 and Environmental Protection' Debreceni Jogi Mühely (2nd issue, 2012) <http://www.debrecenijogimuhely.hu/archivum/2_2012/ the_new_hungarian_constitution_of_2011_and_environmental_protection/ $>$ accessed 5 May 2015.

Kerschner, F., Jahrbuch des Österreichischen und europáischen Umweltrechts (Manz Verlag 2014)

Kilényi, G., A környezetvédelmi jog elméleti alapjai [The Theoretical Foundations of Environmental Law] (Magyar Tudományos Akadémia Állam- és Jogtudományi Intézet 1979)

Krämer, L., Az Európai Unió környezeti joga [The Environmental Law of the EU] (Dialóg Campus 2012)

Percival, RV., 'Environmental Law in the Twenty-first Century' (2007) 1 Virginia Environmental Law Journal $1-35$.

Purdy, J., 'American Natures: The Shape of Conflict in Environmental Law' (2012) 36 Harv. Envtl. L. Rev. 169-220.

Raisz, A., 'A Constitution's Environment, Environment in the Constitution - Process and Background of the New Hungarian Constitution' (2012) 1 Est Europa - La revue 37-70.

Ruhl, JB and J. Salzman, 'The Law and Policy Beginnings of Ecosystem Services' (2007) 2 Journal of Land Use 157-172. 
Sands, P., Principles of international environmental law (Cambridge University Press 2003)

Schnedl, G., Umweltrecht im Überblick (2nd edn, Facultas 2014)

Shelton, D., 'Human Rights and the Environment: What Specific Environmental Rights Have Been Recognized?' (2006) 1 Denver Journal of International Law \& Policy 129-171.

Sólyom, L., 'Address to the ceremonious opening of „The Right to a Healthy Environment and the Representation of Futute Generations' Intetests in the new Hungarian Constitution"' Conference of the Hungarian Parliamentary Commissioner for Future Generations (14 February 2011) $<\mathrm{http} / / / \mathrm{jno} . \mathrm{hu} / \mathrm{hu} /$ ?\&menu=\&doc=alkotmany-konz-osszefoglalo-110214> accessed 25 May 2015.

Szabó, M., 'A fenntartható fejlődés: nemzetközi jogi elmélet és szerződéses gyakorlat' [Sustainable

Development: The Theory of International Law and Practice of Contracts] in A Raisz (ed) $A$ nemzetközi környezetjog aktuális kihivásai [The Actual Challenges of the International Environmental Law] (Miskolci Egyetem 2012) 162-174. 